\title{
EFFECT OF VARIOUS PRETREATMENTS OF OIL PALM EMPTY FRUIT BUNCH FIBRES FOR SUBSEQUENT USE AS SUBSTRATE ON THE PERFORMANCE OF CELLULASE PRODUCTION BY ASPERGILLUS TERREUS
}

\author{
Mahdi Shahriarinour, ${ }^{\text {a }}$ Mohd Noor Abdul Wahab, ${ }^{\text {a }}$ Shuhaimi Mustafa, \\ Rosfarizan Mohamad, and Arbakariya B. Ariff ${ }^{\mathrm{b}, *}$
}

\begin{abstract}
The possibility of using treated oil palm empty fruit bunch (OPEFB) fibres as substrate for cellulase production by Aspergillus terreus was studied using shaking flask fermentation. The effect of different chemical pretreatments, i.e. formic acid, acetic acid, propylamine, phosphoric acid, and n-butylamine, on the suitability of OPEFB fibres as fermentation substrate was investigated. The findings revealed that pretreatment with these chemicals significantly $(P<0.05)$ increased the cellulose and reduced the lignin contents prior to enzymatic hydrolysis. However, fermentation using OPEFB fibres pretreated with phosphoric acid gave the highest cellulase production, which was related to high cellulose content. Further improvement in cellulase production was obtained when the chemically pretreated OPEFB fibres were subsequently treated hydrothermally (autoclaved at $160^{\circ} \mathrm{C}$ for $10 \mathrm{~min}$ ) and then biologically (using effective microorganisms). The final activity of the three main components of cellulase (FPase, CMCase, and $\beta$-glucosidase) obtained in fermentation by $A$. terreus using optimally treated OPEFB fibres was $\left(0.77 \mathrm{U} \mathrm{mL}^{-1}, 8.5 \mathrm{U} \mathrm{mL}^{-1}\right.$, and $\left.6.1 \mathrm{U} \mathrm{mL}^{-1}\right)$, respectively. The production of all these three major components of cellulase using pretreated OPEFB fibres (i.e. chemical, hydrothermal, and biological) were about three times higher than those obtained from fermentation using untreated OPEFB fibres.
\end{abstract}

Key words: Cellulase; Endoglucanas; $\beta$-glucosidase; Pretreatment; Phosphoric acid; Aspergillus terreus; Oil palm empty fruit bunch

Contact information: a: Department of Microbiology, Faculty of Biotechnology and Biomolecular Sciences, Universiti Putra Malaysia, 43400 Serdang, Selangor, Malaysia; b: Department of Bioprocess Technology, Faculty of Biotechnology and Biomolecular Sciences, Universiti Putra Malaysia, 43400 Serdang, Selangor, Malaysia. *Corresponding author’s e-mail: arbarif@biotech.upm.edu.my

\section{INTRODUCTION}

Bioconversion of lignocellulosic waste materials to chemicals and fuels has received great interest due to the fact that it is a green technology, which is renewable and widespread in nature (Kumar et al. 2008). Cellulose in lignocellulosic materials is physically linked with hemicellulose, as well as physically and chemically linked with lignin (Mussatto et al. 2008). The crystalline structure of cellulose that is embedded with the lignin matrix and hemicelluloses consequently leads to very few reactive sites for cellulosic enzymes. Cellulases, which can convert cellulose into glucose, are highly specific in their actions and have no direct hydrolytic effect on lignin and hemicellulose. 
Being macromolecular, cellulase enzymes cannot penetrate through lignin seal surrounding the cellulose fibres. To overcome the lignin and hemicellulose barrier hindrance, many methods of treatment have been suggested and thoroughly investigated (Lee et al. 1997) for the last decade aim at improving the biodegradability of the crop residues. Therefore, the physical, chemical, and biological pretreatments are needed to disrupt the rigid lignocellulose structure. In addition, increased in the amorphous region of cellulose is required to maximize cellulose accessibility and bioconversion yields (Kim and Mazza 2008; Ohgren et al. 2007).

Pretreatment is an essential stage in the enzymatic hydrolysis of lignocellulosic biomass for subsequent use as substrates in the production of bioethanol and other metabolites such as industrial enzymes. The major purpose of any pretreatments is to modify or to remove compositional and configurationally impediments to hydrolysis, followed by degradation processes that increase the digestibility, improve the rate of enzyme hydrolysis, and increase the yields of intended products (Hendriks and Zeeman 2009). The biomass can be treated using different methods, depending on the type, composition, and subsequent processing technology to be applied. Furthermore, biological degradation of lignin by microorganisms has been reported by Congress (1984), indicating that bio-delignification may be used as effective approach in the future for the treatment of lignocellulosic materials. However, this method was claimed as an expensive method with low yields after a long reaction time. In addition, the microorganism use in bio-delignification was also poisoned by lignin derivatives. Nevertheless, there are some advantages of using biological pretreatment, such as low energy utilization and moderate environmental conditions (Balat et al. 2008).

During the process of extraction of palm oil from oil palm fruit, oil palm empty fruit bunch (OPEFB) is generated as biomass waste containing a high content of cellulosic materials. Approximately fifteen million tons of OPEFB biomass waste is produced annually throughout Malaysia by palm oil mills. The fresh OPEFB consists of $30 \%$ solid, which contains $65.5 \%$ holocellulose, $21.2 \%$ lignin, $3.5 \%$ ash, $5.6 \%$ hot water soluble substances, and 4.1\% alcohol-benzene soluble fractions (Thambirajah et al. 1995). This biomass is normally burned in incinerators by palm oil mills, which generate environmental pollution problems in nearby localities. OPEFB has also been used as composting materials (Baharuddin et al. 2009). The use of OPEFB as substrate of fermentation for production of valuable products such as industrial enzymes is not intensively studied. Cellulase is widely used in various industries such as animal food production, starch processing, malting and brewing, grain alcohol fermentation, extraction of fruit and vegetable juices, and manufacture of pulp, paper manufacture, and textiles (Adsul et al. 2007). The demand for cellulase is increasing enormously with the growing industries related to its applications.

The main objective of the present work was to investigate the possibility of using OPEFB fibres as substrate for cellulase production by Aspergillus terreus. The effect of various physical, chemical, and biological pretreatments on the alteration of cellulose structure as well as hemicellulose and lignin content in the OPEFB fibres was first investigated. Subsequently, the treated OPEFB fibres were used as substrate for cellulase production by $A$. terreus in shake flask cultures. 


\section{MATERIALS AND METHODS}

\section{Microorganism}

Aspergillus terreus was used in this study for cellulase production. This mould was isolated from the compost of OPEFB collected from a local factory located at Sri Ulu Langat, Dengkil, Selangor, Malaysia. The mould was grown on potato dextrose agar (Difco) at $30^{\circ} \mathrm{C}$ for 7 days for the development of spores and then stored at $4{ }^{\circ} \mathrm{C}$, for subsequent use in inoculum preparation.

\section{Chemical Pretreatment}

The OPEFB fibres obtained from the mill had an average length of $10 \mathrm{~cm}$. The fibres were first washed with water, dried, and shredded by grinding in a hammer mill (Mill Powder Tech Solutions, Taiwan), whereby their size was decreased to an average of $1 \mathrm{~mm}$ length. In a preliminary experiment, the OPEFB fibres were delignified by mixing approximately $20 \mathrm{~g}$ of OPEFB fibres with $200 \mathrm{~mL}$ distilled water, $0.8 \mathrm{~mL}$ of different chemical solutions and $2.5 \mathrm{~g}$ of sodium chlorite $\left(\mathrm{NaClO}_{2}\right)$. Sodium chlorite with a chemical addition gave rise to high dissolution of lignin and hemicelluloses. The mixture was placed in a water bath at $70^{\circ} \mathrm{C}$ for $12 \mathrm{~h}$. The addition of sodium chlorite $(2.5 \mathrm{~g})$ and different chemical solutions $(0.4 \mathrm{~mL})$ were repeated after $12 \mathrm{~h}$ and $17 \mathrm{~h}$ of treatment (Morrison 2009; Wise et al. 1946). The treated OPEFB fibres were washed with distilled water and collected by filtration through a glass filter (Whatman $\mathrm{GF} / \mathrm{C}, 47 \mathrm{~mm}$ ) followed by oven-drying at $60^{\circ} \mathrm{C}$. The different types of chemical used to treat the OPEFB fibres are categorized as follows;

(1) Formic acid $(\mathrm{HCOOH})$

(2) Acetic acid $\left(\mathrm{CH}_{3} \mathrm{COOH}\right)$

(3) Propylamine $\left(\mathrm{C}_{3} \mathrm{H}_{7} \mathrm{NH}_{2}\right)$

(4) Phosphoric acid $\left(\mathrm{H}_{3} \mathrm{PO}_{4}\right)$

(5) n-butylamine $\left(\mathrm{C}_{4} \mathrm{H}_{11} \mathrm{~N}\right)$

\section{Hydrothermal Pretreatment}

The chemically treated OPEFB fibres were exposed to hydrothermal treatment by autoclaving at $160^{\circ} \mathrm{C}$ for $10 \mathrm{~min}$, and then rinsed thoroughly with deionised water and collected on a glass fibre filter (Whatman $\mathrm{GF} / \mathrm{C}, 47 \mathrm{~mm}$ ). For the removal of hemicellulose, the fibres were further treated by immersing into $4 \% \mathrm{NaOH}$ solution and heated at $70^{\circ} \mathrm{C}$ for $24 \mathrm{~h}$. The treated fibres were washed with distilled water and collected using a glass fibre filters (Whatman GF/C, $47 \mathrm{~mm}$ ) until no traces of acid or alkali could be detected. The treated fibres were then dried in an oven at $60^{\circ} \mathrm{C}$ for two days.

\section{Biological Pretreatment}

The effective microorganisms (EM1 inoculants), which comprised a mixture of several microorganisms, were used for biological treatment. This mixed culture was widely applied to many environments in order to break down the organic components of materials (Higa and Parr 1994). "EM technology" is widely used to improve soil quality and plant growth using a mixture of microorganisms consisting mainly of lactic acid bacteria, purple bacteria, and yeasts. The EM culture was activated by an equal ratio in 
volume with molasses $(1: 1)$ and then diluted 20 times with distilled water. The activated EM was stored at 25 to $30^{\circ} \mathrm{C}$ for 3 to 5 days in a dark place with $\mathrm{pH}$ adjusted to around 3.7. The effect of different dilutions $(1: 10,1: 100,1: 200$, and 1:1000) of the effective microorganisms on biological treatment of OPEFB fibres was studied.

\section{Medium and Fermentations}

The basal medium, as described by Mandels and Weber (1969), was utilised for cellulase production by $A$. terreus. This basal medium consisted of $2 \mathrm{~g} / \mathrm{L} \mathrm{KH}_{2} \mathrm{PO}_{4}, 0.3$ $\mathrm{g} / \mathrm{L} \mathrm{MgSO}_{4} .7 \mathrm{H}_{2} \mathrm{O}, 0.3 \mathrm{~g} / \mathrm{L} \mathrm{CaCl}_{2} .2 \mathrm{H}_{2} \mathrm{O}, 2 \mathrm{~g} / \mathrm{L} \mathrm{CoCl}_{2}, 1.6 \mathrm{~g} / \mathrm{L} \mathrm{MnSO}_{4} . \mathrm{H}_{2} \mathrm{O}, 1.4 \mathrm{~g} / \mathrm{L}$ $\mathrm{ZnSO}_{4} \cdot \mathrm{H}_{2} \mathrm{O}, 5 \mathrm{~g} / \mathrm{L} \mathrm{FeSO}_{4} .7 \mathrm{H}_{2} \mathrm{O}, 2 \mathrm{~mL} / \mathrm{L}$ Tween 80 , and $1 \mathrm{~mL} / \mathrm{L}$ of trace element solution. The treated OPEFB fibres $(10 \mathrm{~g} / \mathrm{L})$ were added to the medium as a carbon source supplement. In all fermentations, $100 \mathrm{~mL}$ of the medium $(\mathrm{pH} \mathrm{5.5)}$ was dispensed into a $500 \mathrm{~mL}$ shake flask and inoculated with $5 \mathrm{~mL}$ of spore suspension containing approximately $6 \times 10^{6}$ spores $/ \mathrm{mL}$. The flasks were incubated at $30^{\circ} \mathrm{C}$ in a rotary orbital shaker agitated at $200 \mathrm{rpm}$ for $288 \mathrm{~h}$. Each experiment was performed in triplicates.

\section{Analytical Procedures}

The gravimetric method, as described by Georing and Van Soest (1970) was used to determine hemicellulose, cellulose, and lignin contents in OPEFB fibres.

During cellulase fermentation by $A$. terreus, the culture samples were withdrawn at regular time intervals for analysis. The cultures were centrifuged at $15,000 \mathrm{rpm}$ at $4{ }^{\circ} \mathrm{C}$ for $15 \mathrm{~min}$. The supernatant was analyzed for soluble protein and enzyme activities. Since the separation of mycelium from the OPEFB fibres was not possible, a chemical method based on the measurement of glucosamine was adopted to estimate mycelia weight (Khan and Strange 1975; Ride and Drysdale 1972; Umikalsom et al. 1997). This method involved the production of chitosan from fungal chitin and liberation of glucosamine from chitosan through a chemical reaction. Chitin is an insoluble linear polymer of $\alpha-1$, 4-linked- $N$-acetylglucosamine units produced by most fungi but not found in plant tissues. Glucosamine concentration in the mycelia of A. terreus was proportional to the mycelial weight and remained constant throughout the growth phases.

The carboxymethylcellulase (CMCase), filter-paper-hydrolysing (FPase), and $\beta$ glucosidase activities were determined using the method described by Wood and Bhat (1988). The CMCase activity was determined by measuring the reducing sugars produced from $2 \%(\mathrm{w} / \mathrm{v})$ carboxymethylcellulose, while the FPase activity was determined by estimating the reducing sugars liberated from filter paper. Both reactions were carried out in $0.05 \mathrm{M}$ sodium acetate buffer of $\mathrm{pH} 5$ and incubated at $50^{\circ} \mathrm{C}$. The reaction time was 30 min and $60 \mathrm{~min}$ for CMCase and FPase, respectively. One unit of CMCase and FPase activity was defined as $1 \mu \mathrm{mol}$ reducing sugar released $/ \mathrm{mL}$ enzyme $/ \mathrm{min}$. $\beta$-glucosidase activity was determined based on the release of $p$-nitrophenol from $p$-nitrophenyl- $\beta$-Dglucopyranoside (Fluka), where the absorbance of the reaction mixture was measured using a spectrophotometer (Shimadzu, UV-1601 PC). In this case, one unit of $\beta$ glucosidase activity is defined as $1 \mu \mathrm{mol} p$-nitrophenol liberated $/ \mathrm{mL}$ of enzyme $/ \mathrm{min}$. The specific activity of the enzyme is defined as units/mg protein.

The protein content was determined by the Bradford method (Bradford 1976)

using bovine serum albumin as a standard. In this method, the interference of the 
absorbance due to the presence of chemical used in the treatment was taken into account using a blank containing chemically treated samples.

\section{Scanning Electron Microscope (SEM) Analysis}

In the first stage of the preparation, the sample was cut and put in separate vials. The sample was fixed in fixative ( $4 \%$ glutaraldehyde) for 12 to $24 \mathrm{~h}$ at $4{ }^{\circ} \mathrm{C}$. The sample was washed with $0.1 \mathrm{M}$ sodium cacodylate buffer for 3 changes of $10 \mathrm{~min}$ each and then post-fixed with $1 \%$ osmium tetroxide for $2 \mathrm{~h}$ at $4{ }^{\circ} \mathrm{C}$. The fixed sample was washed with $0.1 \mathrm{M}$ sodium cacodylate buffer for 3 changes of $10 \mathrm{~min}$ each. The sample was dehydrated using a series of acetone as follows: 35\% (10 min), 50\% (10min), 75\% (10 $\min$ ), $95 \%$ (10 $\mathrm{min})$, and 100\% (15 min) for 3 changes. The dehydrated samples were transferred into the specimen basket (poro-spot) and dried in a critical point dryer machine (CPD) for about half an hour. The dried samples were mounted on aluminum specimen stubs using electrically conducting carbon and sputter-coated with a gold layer using argon gas as the ionizing plasma. Imaging was performed using scanning electron microscopy (S-450 SEM, Philips) with secondary electrons at a $20-\mathrm{KV}$ acceleration voltage, set at room temperature.

\section{Statistical Analysis}

The results were compared by one-way analysis of variance (one-way ANOVA) and multiple range tests to find the differences between the measurement means at 5\% (0.05) significance level. The data were analyzed using Minitab 14 statistical software (Minitab, PA, USA).

\section{RESULTS AND DISCUSSION}

\section{Changes in the Chemical Compositions of OPEFB with Different Pretreatments}

The removal of hemiellulose and lignin from lignoellulosic biomass was achieved by different pretreatments, including physical, chemical, and biological methods. The chemical compositions of OPEFB fibres, untreated and treated with different chemical solutions are given in Table 1. In general, cellulose content in OPEFB fibres treated with different chemicals was significantly $(P<0.05)$ increased as compared to untreated fibres. On the other hand, hemicellulose and lignin contents were significantly reduced. Among the chemical treatments investigated, phosphoric acid gave the highest amount of cellulose content $(52.4 \%)$. This treatment also reduced the hemicellulose and lignin contents to $16.1 \%$ and $6.1 \%$, respectively. Although the treatment of OPEFB fibres with formic acid and propylamine reduced the lignin content significantly as compared to the untreated OPEFB fibres, the cellulose content was not increased significantly. In comparison to untreated OPEFB fibre, soaking with various chemicals without further hydrothermal treatment did not significantly $(P<0.05)$ increased cellulose and reduced hemicellulose content. Hydrothermal treated OPEFB fibre with acetic acid, phosphoric acid and N-butyamine at $160^{\circ} \mathrm{C}$ for $10 \mathrm{~min}$, significantly $(P<0.05)$ increased cellulose and reduced hemicellulose content. 
Table 1. Chemical Composition of Untreated and Treated OPEFB Fibres with Different Types of Chemical Solution

\begin{tabular}{|c|c|c|c|c|c|}
\hline \multirow[t]{2}{*}{ Treatment } & \multicolumn{5}{|c|}{ Chemical Composition (\%) } \\
\hline & Cellulose & Hemicellulose & Lignin & Ash & Others $^{m}$ \\
\hline Untreated & $50.3 \pm 1.5^{\mathrm{a}}$ & $21.7 \pm 0.3^{\mathrm{a}}$ & $10.0 \pm 0.4^{\mathrm{a}}$ & $0.5 \pm 0.05^{\mathrm{a}}$ & $17.5 \pm 3.87^{\mathrm{a}}$ \\
\hline \multicolumn{6}{|c|}{ Chemical treatment } \\
\hline Formic acid & $50.9 \pm 0.3^{a}$ & $18.5 \pm 0.1^{b}$ & $7.8 \pm 0.3^{b}$ & $0.5 \pm 0.03^{\mathrm{a}}$ & $22.3 \pm 1.57^{b}$ \\
\hline Acetic acid & $51.8 \pm 0.8^{\mathrm{b}}$ & $16.9 \pm 0.2^{c}$ & $6.5 \pm 0.4^{c}$ & $0.7 \pm 0.07^{b}$ & $24.1 \pm 1.86^{b}$ \\
\hline Propylamine & $50.5 \pm 1.2^{\mathrm{a}}$ & $19.1 \pm 0.4^{d}$ & $8.9 \pm 0.3^{d}$ & $0.4 \pm 0.06^{c}$ & $21.1 \pm 2.94^{b}$ \\
\hline Phosphoric acid & $52.4 \pm 0.9^{d}$ & $16.1 \pm 1.1^{\mathrm{e}}$ & $6.1 \pm 0.9^{c}$ & $0.8 \pm 0.04^{d}$ & $24.6 \pm 2.41^{\mathrm{b}}$ \\
\hline N-butylamine & $51.3 \pm 0.2^{\mathrm{b}}$ & $17.4 \pm 0.4^{\dagger}$ & $7.3 \pm 0.2^{b}$ & $0.6 \pm 0.03^{\mathrm{e}}$ & $23.4 \pm 3.15^{\mathrm{b}}$ \\
\hline \multicolumn{6}{|c|}{ Chemical treatment followed hydrothermal treatment } \\
\hline Formic acid & $52.3 \pm 0.7^{\mathrm{b}}$ & $12.2 \pm 0.7^{\mathrm{b}}$ & $7.5 \pm 0.4^{\mathrm{b}}$ & $0.2 \pm 0.01^{\mathrm{b}}$ & $27.8 \pm 3.11^{\mathrm{b}}$ \\
\hline Acetic acid & $54.5 \pm 1.1^{\mathrm{c}}$ & $9.81 \pm 0.5^{\mathrm{c}}$ & $6.3 \pm 0.2^{c}$ & $0.5 \pm 0.04^{\mathrm{a}}$ & $28.8 \pm 2.74^{\mathrm{b}}$ \\
\hline Propylamine & $51.7 \pm 1.3^{\mathrm{b}}$ & $14.5 \pm 0.1^{\mathrm{d}}$ & $8.4 \pm 0.5^{d}$ & $0.3 \pm 0.02^{c}$ & $25.1 \pm 3.23^{b}$ \\
\hline Phosphoric acid & $56.7 \pm 1.4^{\mathrm{d}}$ & $7.30 \pm 0.2^{\mathrm{e}}$ & $6.1 \pm 0.3^{c}$ & $0.7 \pm 0.05^{d}$ & $29.2 \pm 2.81^{\mathrm{b}}$ \\
\hline N-butylamine & $54.1 \pm 0.9^{c}$ & $10.8 \pm 0.3^{\dagger}$ & $7.1 \pm 0.1^{b}$ & $0.4 \pm 0.01^{\mathrm{e}}$ & $27.6 \pm 2.38^{b}$ \\
\hline \multicolumn{6}{|c|}{$\begin{array}{l}\text { a-f Values in the same column with different superscripts are significantly different }(P<0.05) \\
\text { mother content of plant materials such as lipid, starch, sugars, protein and organic acid } \\
\text { Data are presented on a dry matter basis and lose of dry matter occurring in processing } \\
\text { steps is accounted in the calculations. } \\
\text { Values are means of triplicate with } \pm \text { standard deviation }\end{array}$} \\
\hline
\end{tabular}

The chemical composition of OPEFB fibres, treated with phosphoric acid and hydrothermal, followed with the treatment using different dilutions of effective microorganisms (EM) are given in Table 2.

Table 2. Chemical Composition of OPEFB Fibres Pretreated with a Combination of Chemicals, Hydrothermal and with Different Dilutions of Effective Microorganisms

\begin{tabular}{lccccc}
\hline \multicolumn{1}{l}{ Effective Micro-organisms } & \multicolumn{4}{c}{ Chemical Composition (\%) } \\
\hline \multirow{3}{*}{ without dilution } & Cellulose & Hemicellulose & Lignin & Ash & Others $^{\mathrm{m}}$ \\
\cline { 2 - 6 } $1: 10$ & $59.1 \pm 1.1^{\mathrm{a}}$ & $4.05 \pm 0.1^{\mathrm{a}}$ & $4.11 \pm 0.3^{\mathrm{a}}$ & $0.6 \pm 0.07^{\mathrm{a}}$ & $32.1 \pm 1.03^{\mathrm{a}}$ \\
$1: 100$ & $63.4 \pm 1.9^{\mathrm{b}}$ & $4.30 \pm 0.6^{\mathrm{a}}$ & $4.20 \pm 0.2^{\mathrm{a}}$ & $0.6 \pm 0.03^{\mathrm{a}}$ & $27.5 \pm 1.36^{\mathrm{b}}$ \\
$1: 200$ & $61.6 \pm 0.7^{\mathrm{c}}$ & $5.81 \pm 0.2^{\mathrm{b}}$ & $4.64 \pm 0.3^{\mathrm{b}}$ & $0.6 \pm 0.06^{\mathrm{a}}$ & $27.3 \pm 1.02^{\mathrm{b}}$ \\
$1: 1000$ & $59.5 \pm 1.2^{\mathrm{a}}$ & $6.47 \pm 0.3^{\mathrm{c}}$ & $5.12 \pm 0.5^{\mathrm{c}}$ & $0.7 \pm 0.05^{\mathrm{b}}$ & $28.2 \pm 1.01^{\mathrm{b}}$ \\
& $57.3 \pm 1.5^{\mathrm{d}}$ & $7.15 \pm 0.3^{\mathrm{d}}$ & $5.96 \pm 0.2^{\mathrm{d}}$ & $0.7 \pm 0.03^{\mathrm{b}}$ & $28.8 \pm 1.02^{\mathrm{b}}$
\end{tabular}

\footnotetext{
${ }^{a-d}$ Values in the same column with different superscripts are significantly different $(P<0.05)$

${ }^{m}$ Other content of plant materials such as lipid, starch, sugars, protein and organic acid

Values are means of triplicate \pm standard deviation
} 
The highest content of cellulose (63.4\%) was found after treatment with 1:10 dilution of EM, while the treatment with undiluted EM reduced hemicellulose and lignin to a greater extent. Obviously, reduced cellulose component $(59.1 \%)$ was due to the activity of EM which disrupted the structure of OPEFB fibres

Table 3 displays the chemical composition of OPEFB fibres, untreated and treated with different methods. The OPEFB fibres treated with phosphoric acid followed by hydrothermal treatment significantly $(P<0.05)$ increased the cellulose and reduced the hemicellulose content, while lignin content remained the same. In comparison to untreated OPEFB fibres, cellulose content was increased by $12.7 \%$, while the hemicellulose content was reduced by $66.4 \%$. In addition, the combination of chemical, hydrothermal, and biological treatments increased the cellulose content by about $26.1 \%$ as compared to the content in untreated OPEFB fibres. On the other hand, hemicellulose content was reduced by about $80.1 \%$ as compared to that contained in untreated OPEFB fibres $(21.7 \%)$.

Table 3. Chemical Composition of OPEFB Fibres Pretreated with the Combination of Chemicals, Hydrothermal and Biological Treatments

\begin{tabular}{|c|c|c|c|c|c|}
\hline Treatment & \multicolumn{5}{|c|}{ Chemical Composition (\%) } \\
\hline & Cellulose & Hemicellulose & Lignin & Ash & Others $^{m}$ \\
\hline Untreated & $50.3 \pm 1.5^{a}$ & $21.7 \pm 0.3^{a}$ & $10.0 \pm 1.4^{a}$ & $0.5 \pm 0.05^{a}$ & $17.5 \pm 3.87^{\mathrm{a}}$ \\
\hline Treated wit & $\begin{array}{l}\text { sphoric acid } \\
52.4 \pm 0.9^{b}\end{array}$ & $16.1 \pm 1.1^{b}$ & $6.10 \pm 0.9^{b}$ & $0.8 \pm 0.04^{b}$ & $24.6 \pm 2.41^{b}$ \\
\hline Treated wit & $\begin{array}{l}\text { ssphoric acid } \\
56.7 \pm 1.4^{\mathrm{C}}\end{array}$ & $\begin{array}{l}\text { owed hydrother } \\
7.30 \pm 0.2^{c}\end{array}$ & $\begin{array}{l}\text { al treatment } \\
6.10 \pm 0.3^{\mathrm{b}}\end{array}$ & $0.7 \pm 0.05^{\mathrm{C}}$ & $29.2 \pm 2.81^{\mathrm{c}}$ \\
\hline $\begin{array}{l}\text { Treated wit } \\
{ }^{\mathrm{a}-\mathrm{d}} \text { Values ir } \\
{ }^{\mathrm{m}} \text { Other con } \\
\text { Values are }\end{array}$ & $\begin{array}{l}\text { sphoric acid } \\
63.4 \pm 1.9^{d} \\
\text { same colum } \\
\text { of plant mate } \\
\text { ns of triplicate }\end{array}$ & $\begin{array}{l}\text { lowed by hydro } \\
4.30 \pm 0.6^{\mathrm{d}} \\
\text { th different sup } \\
\text { such as lipid, } \mathrm{s} \\
\text { standard deviati }\end{array}$ & $\begin{array}{l}\text { ermal treatm } \\
4.20 \pm 0.2^{c} \\
\text { scripts are s } \\
\text { rch, sugars, }\end{array}$ & $\begin{array}{l}\text { and biologi } \\
0.6 \pm 0.03^{d} \\
\text { ficantly diffe } \\
\text { tein and ors }\end{array}$ & $\begin{array}{l}\text { treatment } \\
27.5 \pm 1.36^{\mathrm{b}} \\
\text { ht }(P<0.05) \\
\text { ic acid }\end{array}$ \\
\hline
\end{tabular}

Dilute acid has been shown to be a good alternative to selectively remove the hemicellulose fraction, generating a solid residue basically composed of cellulose and lignin (Mussatto and Roberto 2005). Conversely, the use of diluted alkali is effective for lignin removal (Mussatto et al. 2006). Cellulose-enriched material can be formed using these pretreatments in sequential steps. Hence, OPEFB fibres shall be initially pretreated before the enzymatic hydrolysis to remove hemicellulose and lignin fractions, as a consequence obtaining substrates with high cellulose content.

\section{Cellulase Production by $A$. terreus Using OPEFB as Substrate Pretreated with Various Treatments}

Production of cellulase by $A$. terreus using OPEFB fibres pretreated with different chemicals is shown in Fig. 1. Among the chemicals investigated, phosphoric acid gave the highest production of all three major cellulase components, i.e. FPase $(0.55 \mathrm{U} / \mathrm{mL})$, carboxymethylcellulase $(7.9 \mathrm{U} / \mathrm{mL})$, and $\beta$-glucosidase $(4.5 \mathrm{U} / \mathrm{mL})$, followed by acetic acid and n-butylamine. The chemical treatment caused physical disruption of cellulose 
external structure, which might permit greater fungal accessibility to the fermentable molecules. High level of cellulase production from the fermentation of OPEFB fibres treated with phosphoric acid compared to other chemicals was possibly due, in part, to better swelling of OPEFB fibres surface.
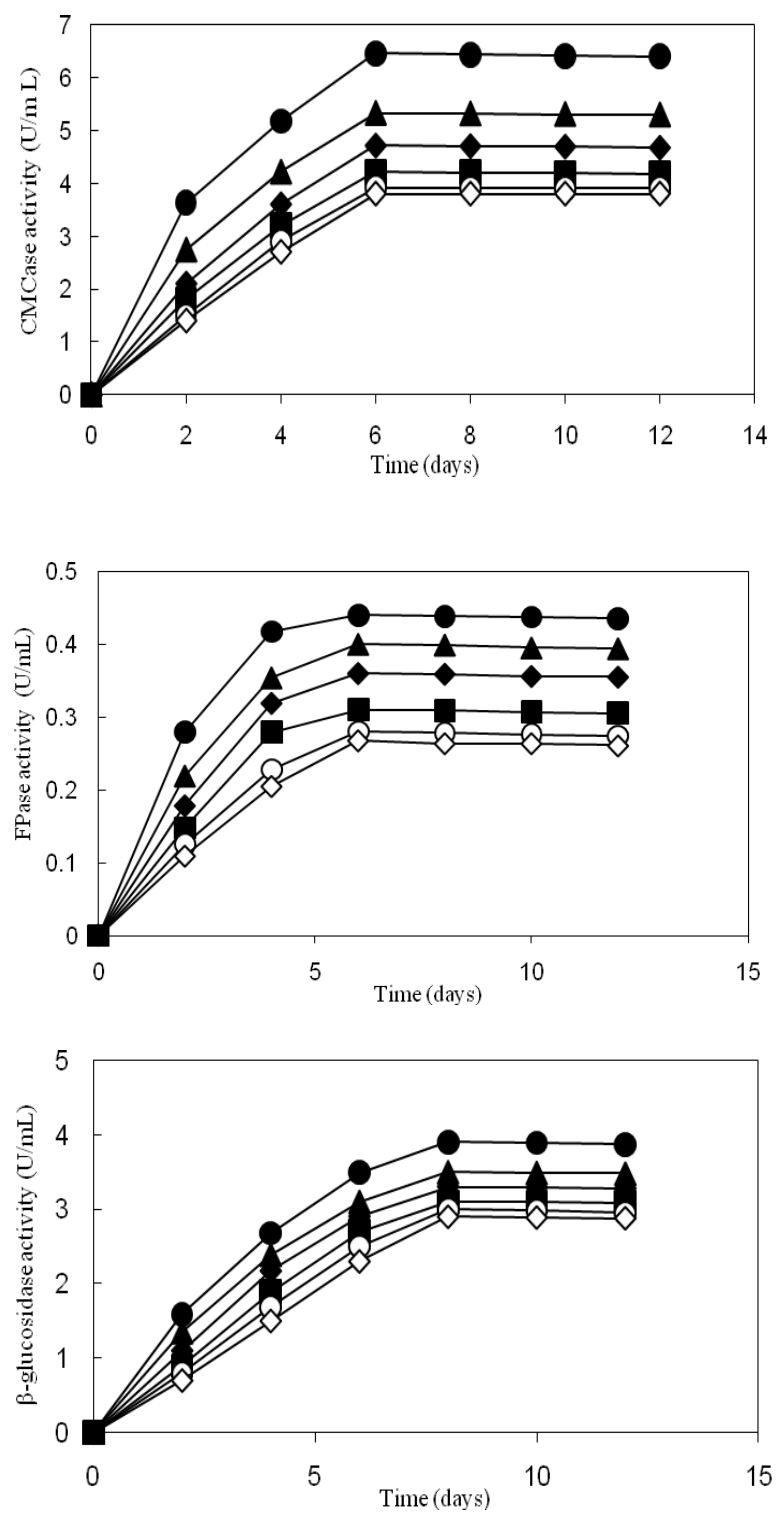

Fig. 1. Cellulase production by $A$. terreus using OPEFB fibre treated with different types of chemicals. Values are means of three replicates with \pm SD of $2 \%$ of measured values. Cellulase activities in cultures containing OPEFB fibre treated with phosphoric acid, acetic acid, and Nbutyamine increased significantly $(P<0.05)$. $(\diamond)$ untreated; $(\bullet)$ phosphoric acid; $(\mathbf{\Delta})$ acetic acid; $(\diamond)$ n-butylamine; ( $\mathbf{a})$ formic acid; (o) propylamine.

Cellulase production by $A$. terreus using hydrothermal OPEFB fibres treated with various chemicals is shown in Fig. 2. Hydrothermal chemically-treated OPEFB fibres improved production of all three major cellulase components compared to non- 
hydrothermal OPEFB. In general, hydrothermal chemically-treated OPEFB fibres increased the cellulose and reduced the hemicellulose and lignin contents. The cellulose content in hydrothermal treated OPEFB with subsequent treatment with different chemicals is shown in Table 1.
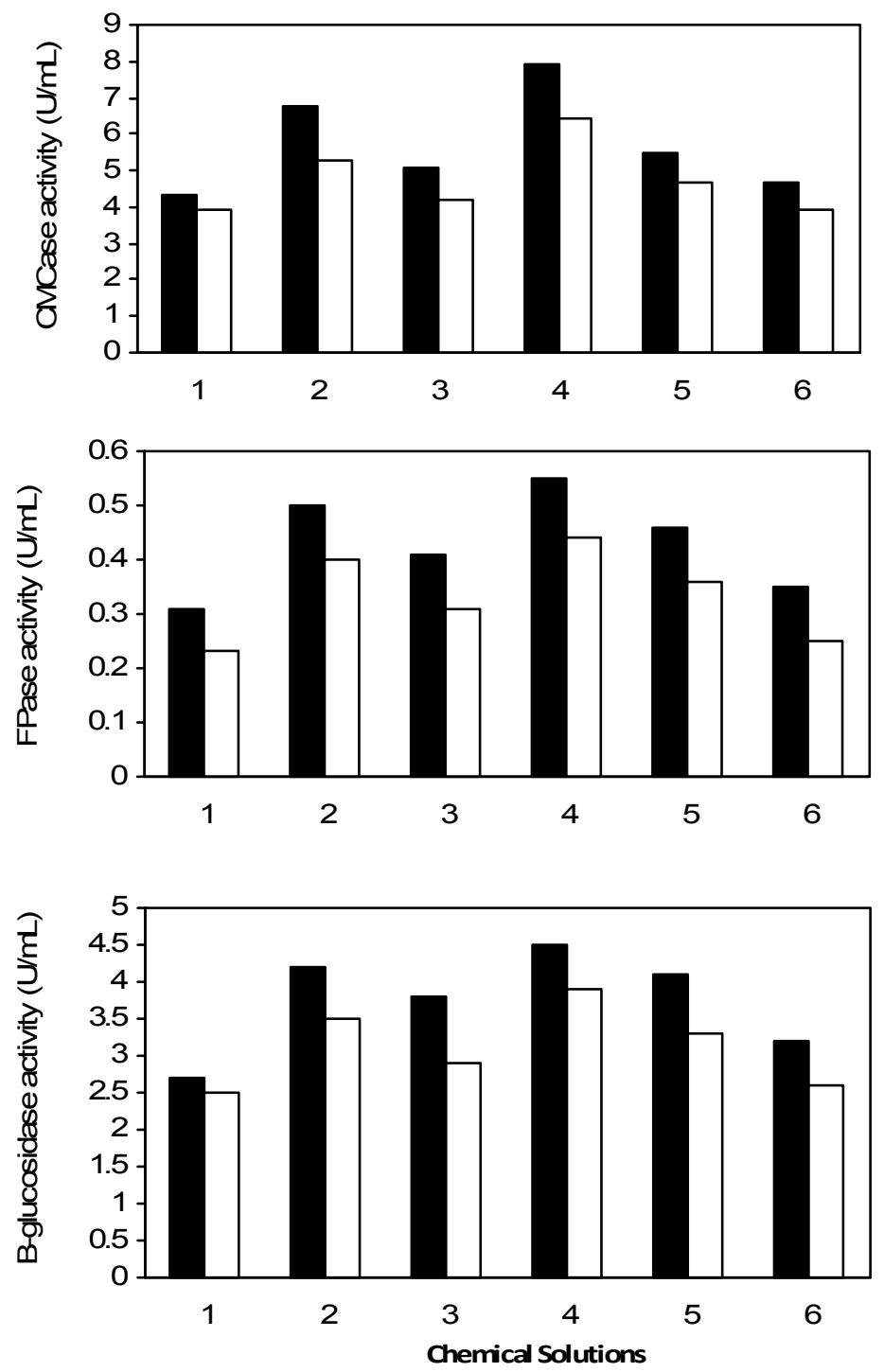

Fig. 2. Effect of hydrothermal treatment following chemical treatment of OPEFB fibre on cellulase production by $A$. terreus. Values are means of three replicates with \pm SD of $2 \%$ of measured values. Cellulase activities in cultures using hydrothermal-chemically treated OPEFB fibre increased significantly $(P<0.05)$ when compared to culture using non-hydrothermal-chemically treated OPEFB fibre. (1) untreated; (2) acetic acid; (3) formic acid; (4) phosphoric acid; (5) nbutylamine; (6) propylamine. ( $\mathbf{a})$ hydrothermal treated; $(\square)$ non- hydrothermal treated

In current practice, sulphuric and hydrochloric acids are used in industrial processses to convert solubilized hemicelluloses to fermentable sugars (Saha et al. 2005), which eliminate or reduce the need for hemicellulase enzyme mixtures. However, this acid treatment method requires a neutralization process, expensive equipment, and has to 
be operated at high temperature. In addition, the process also generates toxic by-products such as furfural and hydroxymethylfurfural (Kim and Mazza 2008). Hemicellulose and lignin can also be solubilized efficiently in concentrated phosphoric acid at $50^{\circ} \mathrm{C}$ (Canettieri 2007). Pretreatments using weak acid and phosphoric acid have been claimed as an environmental-friendly solution. Efficient fractionation of lignocellulosic materials with reduced cellulose crystallinity could be achieved using this technique, resulting in energy savings and reduction in the generation of toxic by-products (Sun and Cheng, 2002, 2005; Wyman et al. 2005; Zhang et al. 2007). Hydrolysis of lignocellulosic biomass can be activated by thermal treatment in the presence of phosphoric acid (Suarez-Garcia et al. 2002).

The performance of cellulase fermentation by $A$. terreus using OPEFB fibres treated biologically using different dilutions of EM is shown in Table 4. The highest cellulase activity was obtained from fermentation using OPEFB treated with EM at the dilution of 1:10. A slight reduction in growth of $A$. terreus and the production of all three components of cellulase were observed when the inoculum size was diluted above 200 times (1:200). Production of the three main components of cellulase (FPase, CMCase, and $\beta$-glucosidase) by $A$. terreus using OPEFB fibres treated at different stages are given in Table 5. The maximum cell growth and maximum activities of FPase, CMCase, and $\beta$ glucosidase obtained from the fermentation using OPEFB fibres treated optimally with chemical, hydrothermal, and biological treatments revealed the following values; $5.2 \mathrm{~g} / \mathrm{L}$, $0.77 \mathrm{U} / \mathrm{mL}, 8.5 \mathrm{U} / \mathrm{mL}$ and $6.1 \mathrm{U} / \mathrm{mL}$, respectively.

Table 4. Cellulase Production by Aspergillus terreus using OPEFB Fibres Treated Biologically with Different Dilutions of EM

\begin{tabular}{|c|c|c|c|c|c|c|}
\hline $\begin{array}{l}\text { Effective Micro- } \\
\text { organisms }\end{array}$ & $\begin{array}{c}\text { Cell } \\
\text { Growth } \\
(\mathrm{g} / \mathrm{L})\end{array}$ & $\begin{array}{l}\text { FPase } \\
(\mathrm{U} / \mathrm{mL})\end{array}$ & $\begin{array}{c}\text { CMCase } \\
(\mathrm{U} / \mathrm{mL})\end{array}$ & $\begin{array}{c}\beta- \\
\text { glucosidas } \\
\mathrm{e}^{*}(\mathrm{U} / \mathrm{mL})\end{array}$ & $\begin{array}{l}\text { Protein } \\
(\mathrm{mg} / \mathrm{mL})\end{array}$ & $\begin{array}{l}\text { Specific } \\
\text { activity } \\
\text { FPase } \\
(\mathrm{U} / \mathrm{mg})\end{array}$ \\
\hline without dilution & $5.1 \pm 0.01^{a}$ & $0.72 \pm 0.01^{\mathrm{a}}$ & $7.9 \pm 0.03^{a}$ & $5.8 \pm 0.03^{a}$ & $1.17 \pm 0.03^{\mathrm{a}}$ & $0.61^{a}$ \\
\hline $1: 10$ & $5.2 \pm 0.02^{b}$ & $0.77 \pm 0.02^{b}$ & $8.5 \pm 0.04^{b}$ & $6.1 \pm 0.08^{a}$ & $1.18 \pm 0.02^{\mathrm{a}}$ & $0.65^{b}$ \\
\hline $1: 100$ & $4.8 \pm 0.01^{c}$ & $0.54 \pm 0.02^{c}$ & $7.2 \pm 0.03^{c}$ & $5.1 \pm 0.06^{b}$ & $1.11 \pm 0.02^{b}$ & $0.49^{c}$ \\
\hline $1: 200$ & $4.6 \pm 0.02^{d}$ & $0.50 \pm 0.03^{d}$ & $6.9 \pm 0.05^{d}$ & $4.5 \pm 0.05^{b}$ & $1.05 \pm 0.01^{c}$ & $0.47^{d}$ \\
\hline 1:1000 & $4.3 \pm 0.02^{\mathrm{e}}$ & $0.41 \pm 0.03^{\mathrm{e}}$ & $5.8 \pm 0.02^{\mathrm{e}}$ & $3.6 \pm 0.03^{b}$ & $0.93 \pm 0.02^{d}$ & $0.44^{\mathrm{e}}$ \\
\hline
\end{tabular}

Hemicellulose and lignin inhibited the enzymes and protected cellulose against the enzymatic attack (Liao et al. 2005). Based on the removal or reduction of hemicelluloses and lignin, the cellulose crystallinity was decreased, while the porosity and the accessibility of the surface area were enhanced, which in turn, provided a conducive condition for the cellulase enzyme attack on cellulose (Mansfield et al. 1999; Mussatto et al. 2008; Sun and Cheng 2002). 
Table 5. Cellulase production by $A$. terreus Using OPEFB Fibres Pretreated with Different Combinations of Treatment as Substrate

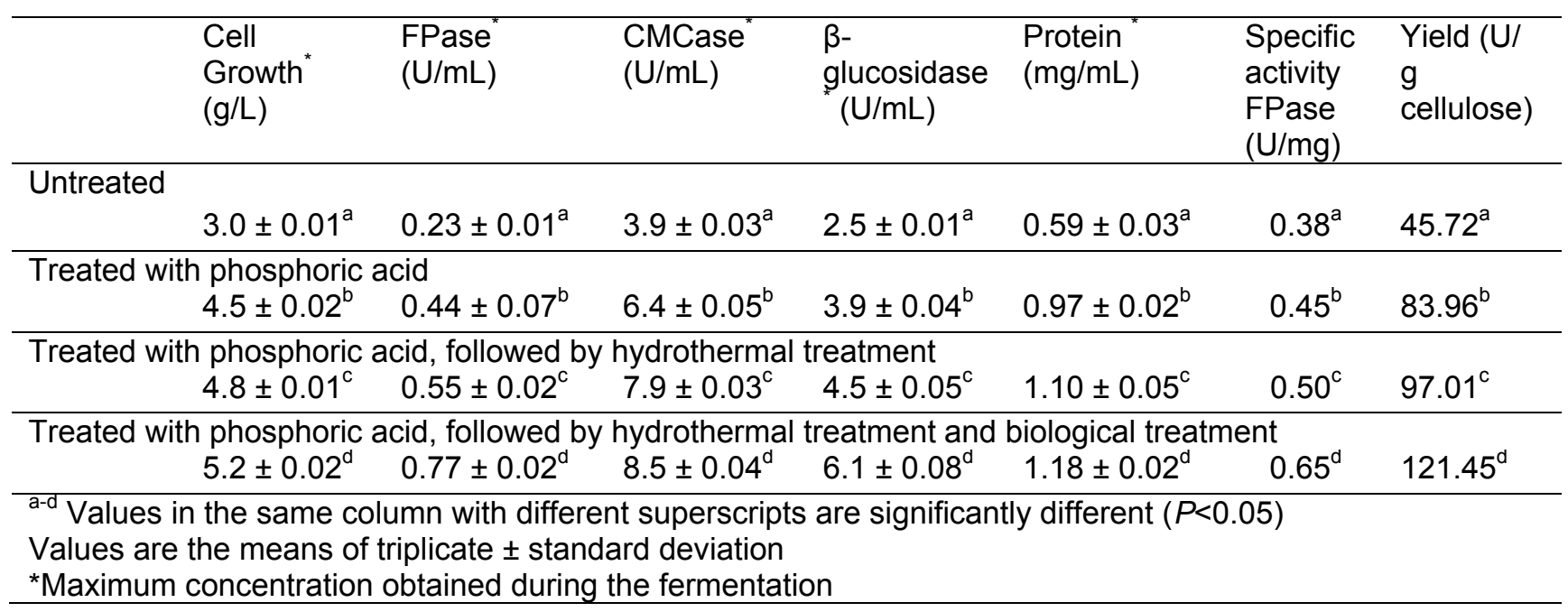

\section{SEM Analysis of OPEFB Treated with Various Treatments}

The efficiency of pretreatments in improving the hydrolysis rate is the result of structural modifications (Mussatto et al. 2008). The fibre surface morphologies of OPEFB samples treated with various treatments were examined under the Scanning Electron Microscopy, and the results are shown in Fig. 3.

The untreated OPEFB fibres showed rigid and highly ordered fibrils, while considerable morphological changes had indeed occurred in the treated OPEFB fibres. In addition, as viewed from the initial connected structure, treated OPEFB fibres were visibly separated and fully exposed. On the contrary, untreated OPEFB fibres seemed a little bit rougher as compared to the surface of the chemically-treated OPEFB fibres, which appeared smoother. Since lignin was decreased by phosphoric acid pretreatment, this may explain the smoother appearance (Fig. 3b). The OPEFB fibres were still only partially defibrated, presumably due to the reduction of hemicellulose content. However, uneven surface of the untreated fibres became smooth after the phosphoric acid treatment, whereby cellulose aggregates (macrofibrils) ran in the direction of the fibres (Fig. 3b).

Figure $3 \mathrm{c}$ shows that the hydrothermal pretreatment at $160^{\circ} \mathrm{C}$ for $10 \mathrm{~min}$ significantly altered the biomass structure of OPEFB as compared to untreated and treated OPEFB fibres with phosphoric acid. Untreated fibres displayed rigid and highly ordered fibrils, whereas the hydrothermally-treated fibres were separated and peeled off from the initial connected structure and fully exposed (Fig. 3c). On the other hand, OPEFB fibres displayed rough surfaces after delignification with phosphoric acid followed by hydrothermal pretreatment. In addition, a larger number of surface crack formations were also visible in the heat-treated OPEFB fibres, suggesting that the surface area and the porosity had been increased. 

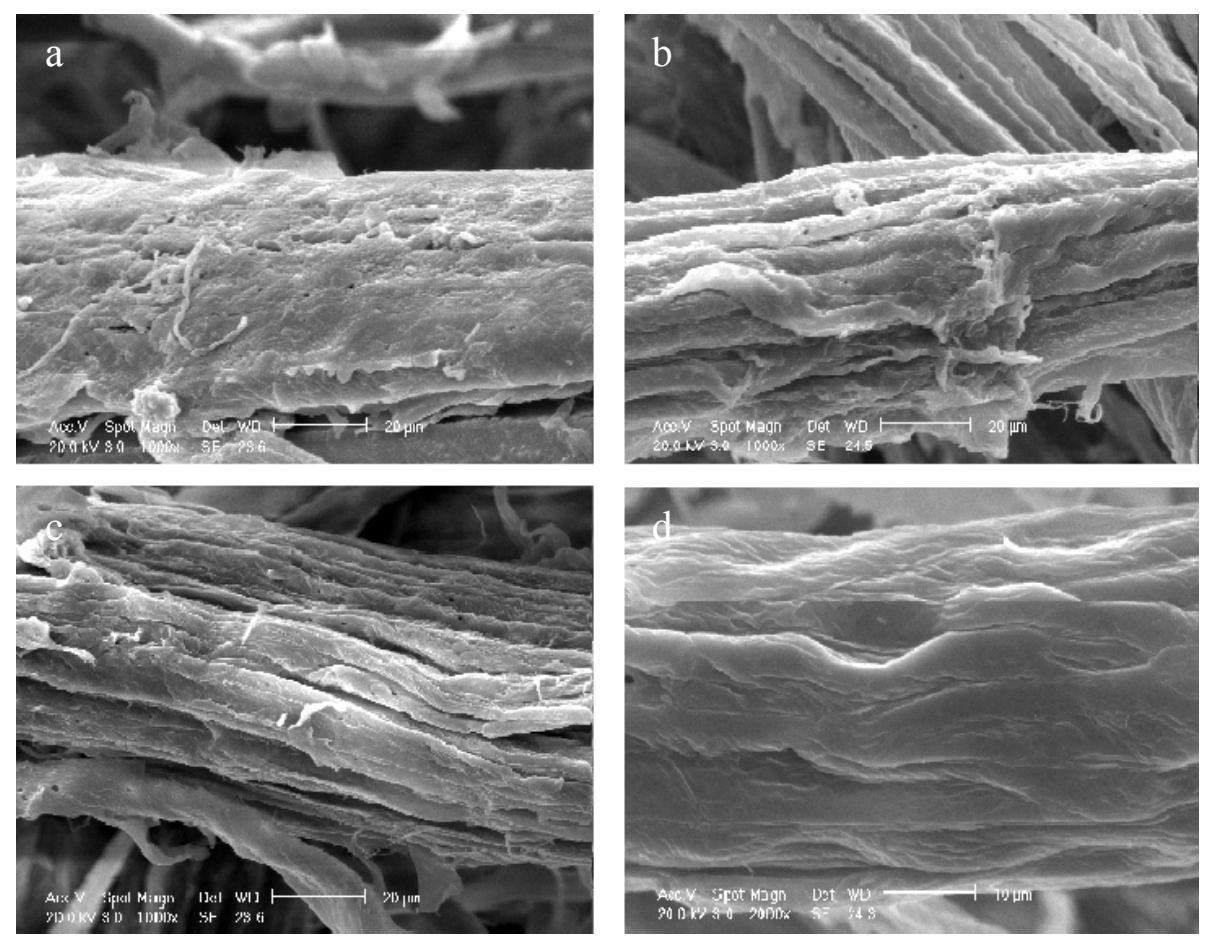

Fig. 3. SEM images of (a) untreated oil palm empty fruit bunch fibres (b) OPEFB fibres treated with phosphoric acid, (c) OPEFB fibres treated with phosphoric acid followed by autoclaving at $160^{\circ} \mathrm{C}$ for $10 \mathrm{~min}$, (d) OPEFB fibres treated biologically with effective microorganisms after previously treated with phosphoric acid followed by autoclaving at $160^{\circ} \mathrm{C}$ for $10 \mathrm{~min}$.

The major effects of hydrothermal treatment were the swelling of cellulose and delignification. The cellulose in OPEFB fibres was separated from the original connected structure and completely uncovered, therefore, enhancing the external surface area and porosity. This means that the fibres were more susceptible to enzymatic and microbial attacks. Hydrothermal treatment has been claimed to be superior and the most important for the pretreatment of lignocellulosic materials as compared to other treatments (Taherzadeh and Karimi 2007). Hydrothermal pretreatment also causes ultrastructural changes and formation of micron-sized pores that enlarge the accessibility and susceptibility of the surface area and make the cellulose more accessible to enzymatic hydrolysis (Zeng et al. 2007). Severe pretreatment normally caused significant increased in the surface area of cellulose available to enzymes and microbial attacks (Ooshima et al. 1990).

After biological treatment, the surface of OPEFB fibres became more uniform and smoother as compared to OPEFB fibres treated with phosphoric acid followed by hydrothermal treatment (Fig. 3d). Dissolution of hemicellulose and lignin fractions as well as the alteration of the morphology and structure of the cellulosic residue occurred during the biological treatments due to enzymatic hydrolysis (Ramos et al. 1993).

Lignin decreases the hydrolysis of cellulose in two different ways; (1) by physical block that inhibits enzyme from gaining access to cellulose, and (2) by non-productively binding the cellulolytic enzymes (Pan et al. 2005). Lignin with irreversible reaction adsorbs the cellulase enzymes, which in turn, impedes the effect on cellulose (Mansfield 
et al. 1999). In the case where the lignin content of lignocellulosic biomass is relatively high, the enzymes are prevented or adsorbed on the lignin, and only a small amount is allowed to adsorb on the substrate surface. Various enzymes can easily be adsorbed on cellulose of lignocellulosic biomass with low lignin content, which enhances enzymatic hydrolysis (Chang and Holtzapple 2000).

Chemical, hydrothermal, and biological pretreatments have been proven to be an effective way to increase the enzymatic digestibility of OPEFB fibres for the conversion into fermentable sugars. The treated OPEFB fibres can be subsequently used as suitable substrate of fermentation for the production of various valuable products such as cellulase. Pretreatments of lignocellulosic materials, including physical, chemical, and biological methods increase the potential changes in cellulose structure, which include pore structure, particle size, lignin and hemicellulose association, crystallinity, and degree of polymerization (Mussatto et al. 2008). Chemical treatment followed by hydrothermal treatment causes a physical disruption of the cellulose external structure, which may permit greater fungal accessibility to the fermentable molecules (Parajo et al. 1995; Young 1992). Hydrothermal is claimed to be the most effective pretreatment and frequently used with the addition of chemicals (Ramos, 2003). In this study, OPEFB fibres were impregnated with phosphoric acid prior to hydrothermal pretreatment. The results from this study also indicated that a combination of chemical, hydrothermal, and biological pretreatments increased the digestibility by increasing the accessibility of the cellulose through a delocalization of lignin and a partial removal of hemicellulose, rather than by the disruption of the cell wall. The removal of hemicelluloses provided a suitable opportunity for being the cause of large pores in the microfibrils; and consequently, increased the accessible pore volume and the specific area. Uncovering of cellulose by removing hemicelluloses and lignin was also important in changing the crystallinity and cracking of the skeletal structure of the cell wall.

Cracks in hydrothermally pretreated fibres are easily digested by the enzymes (Jorgensen et al. 2007). The main advantages of biological delignification include mild reaction conditions, higher product yields, fewer side reactions, and less energy demand (Lee 1997). Lignocellulosic materials in the original structure resist microbial attack. The removal of hemicellulose and lignin causes comprehensive conversion in the formation of cellulose that becomes more vulnerable and open to the swelling on contact with cellulases for hydrolysis (Mansfield et al. 1999).

Increased cellulase production did not solely depend on the amount of cellulose in the medium, but might also depend on other factors such as pore size, surface area, and cellulose crystallinity (Fan et al. 2004). Improved cellulase production from the fermentation using treated OPEFB fibres might be due to the lower lignin and hemicellulose contents, as well as structural changes in cellulose that caused significant increase in the susceptibility of cellulose to microbial and enzymatic attacks. It could be considered that the lower contents of hemicellulose and lignin in the OPEFB fibres gave better performance of enzymatic hydrolysis of cellulose into glucose.

It is important to note that $A$. terreus was able to grow and produce substantial amounts of cellulase in delignified OPEFB fibers, an inexpensive and abundant carbon source, in a simple batch fermentation process using shake flask. For the development of large scale process, the treatment and fermentation processes should be transferred into a 
system that is possible for scaling-up such as a stirred tank bioreactor. The productivity of the fermentation may be improved by using suitable modes of fermentation, such as fed-batch or batch with controlled culture conditions in the bioreactor. The processes need to be optimized using statistical approach such as response surface methodology and artificial neural network. Process parameters important for scaling-up shall also be identified in future work.

\section{CONCLUSIONS}

1. Among the different chemical tested (formic acid, acetic acid, propylamine, phosphoric acid, and n-butylamine), the treatment of oil palm empty fruit bunch (OPEFB) fibres with phosphoric acid gave the highest increase in cellulose and the greatest decrease in lignin content prior to enzyme treatment.

2. The accessibility of the cellulose to enzyme and microbial attacks was further improved using a combination of treatments, which include treatment with phosphoric acid, hydothermal, and then biodelignification using EM. Using this optimal treatment, the cellulose fraction was enhanced by about $26 \%$, while the lignin and hemicellulose fractions were decreased by about 55 and $80 \%$ as compared to untreated OPEFB, respectively.

3. The final activity of the three major component of cellulase (CMCase, FPase, and $\beta$-glucosidase) produced by $A$. terreus in fermentation using optimally treated OPEFB was $8.5 \mathrm{U} / \mathrm{mL}, 0.77 \mathrm{U} / \mathrm{mL}$, and $6.1 \mathrm{U} / \mathrm{mL}$, respectively. This gave the improvement of production by about three times higher than those obtained in fermentation using untreated OPEFB fibres.

4. Results from this study have demonstrated that OPEFB fibres, with appropriate treatments, could be used as potential substrates for cellulase production by $A$. terreus. The supply of this lignocellulosic material is renewable and readily available at the palm oil mill.

\section{ACKNOWLEDGEMENTS}

The first author would like to extend his gratitude for the financial support generously provided by Malaysia's Ministry of Science, Technology and Innovation (MOSTI) under the project 02-01-04-SF0735.

\section{REFERENCES CITED}

Adsul, M. G., Bastawde, K. B., Varma, A. J., and Gokhale, D. V. (2007). "Strain improvement of Penicillium janthinellum NCIM 1171 for increased cellulase production," Bioresource Technology 98, 1467-1473.

Baharuddin, A. S., Wakisaka, M., Shirai, Y., Abd-Aziz, S., Rahman, N. A. and Hassan, M. A. (2009) "Co-composting of empty fruit bunches and partially treated palm oil 
mill effluents in pilot scale," International Journal of Agricultural Research 4(2), 6978.

Balat, M., Balat, H., and Oz, C. (2008). "Progress in bioethanol processing," Progress in Energy and Combustion Science 34(5), 551-573.

Bradford, M. M. (1976). "A rapid and sensitive method for the quantitation of microgram quantities of protein utilizing the principle of protein dye binding," Analytical Biochemistry 72(1-2), 248-254.

Canettieri, E., Rocha, G., and De Carvalho, J. (2007). "Optimization of acid hydrolysis from the hemicellulosic fraction of Eucalyptus grandis residue using response surface methodology," Bioresource Technology 98(2), 422-428.

Chang, V., and Holtzapple, M. (2000). "Fundamental factors affecting biomass enzymatic reactivity," Applied Biochemistry and Biotechnology 84(1), 5-37.

Congress, U. (1984). "Office of Technology Assessment (OTA). Commercial biotechnology: An international analysis." OTA-BA-218. Springfield, Va.: National Technical Information Service.

Fan, L. T., Lee, Y. H., and Beardmore, D. H. (2004). "Mechanism of the enzymatic hydrolysis of cellulose: Effects of major structural features of cellulose on enzymatic hydrolysis," Biotechnology and Bioengineering, 22(1), 177-199.

Goering, H. K., and Van Soest, P. J. (1970). "Forage fiber analysis. Agricultural handbook no. 379," US Department of Agriculture, Washington, DC, 1-20.

Hendriks, A. T. W. M., and Zeeman, G. (2009). "Pretreatments to enhance the digestibility of lignocellulosic biomass," Bioresource Technology 100(1), 10-18.

Higa, T., and Parr, J. F. (1994). "Beneficial and effective microorganisms for a sustainable agriculture and environment," Atami, Japan: International Nature Farming Research Center.

Jørgensen, H., Vibe-Pedersen, J., Larsen, J., and Felby, C. (2007). "Liquefaction of lignocellulose at high-solids concentrations," Biotechnology and Bioengineering, 96(5), 862-870.

Khan, S. R., and Strange, R. N. (1975). "Evidence for the role of a fungal stimulant as a determinant of differential susceptibility of jute cultivars to Colletotrichum corchori," Physiological Plant Pathology 5(2), 157-162,IN17,163-164.

Kim, J., and Mazza, G. (2008). "Optimization of phosphoric acid catalyzed fractionation and enzymatic digestibility of flax shives," Industrial Crops and Products 28(3), 346355.

Kumar, R., Singh, S., and Singh, O. (2008). "Bioconversion of lignocellulosic biomass: Biochemical and molecular perspectives," Journal of Industrial Microbiology and Biotechnology 35(5), 377-391.

Lee, J. (1997). "Biological conversion of lignocellulosic biomass to ethanol," Journal of Biotechnology 56(1), 1-24.

Liao, W., Wen, Z., Hurley, S., Liu, Y., Liu, C., and Chen, S. (2005)."Effects of hemicellulose and lignin on enzymatic hydrolysis of cellulose from dairy manure," Appl. Biochem. Biotechnol. 121, 1017-1030.

Mandels, M., and Weber, J. (1969). "The production of cellulases," Adv. Chem. Ser. 95, 391-414. 
Mansfield, S., Mooney, C., and Saddler, J. (1999). "Substrate and enzyme characteristics that limit cellulose hydrolysis," Biotechnology Progress 15(5), 804-816.

Morrison, I. (2009). "Changes in the cell wall components of laboratory silages and the effect of various additives on these changes," The Journal of Agricultural Science 93(03), 581-586.

Mussatto, S., Dragone, G., Rocha, G., and Roberto, I. (2006). "Optimum operating conditions for brewer's spent grain soda pulping," Carbohydrate Polymers 64(1), 2228.

Mussatto, S., Fernandes, M., Milagres, A., and Roberto, I. (2008). "Effect of hemicellulose and lignin on enzymatic hydrolysis of cellulose from brewer's spent grain," Enzyme and Microbial Technology 43(2), 124-129.

Mussatto, S., and Roberto, I. (2005). "Acid hydrolysis and fermentation of brewer's spent grain to produce xylitol," Journal of the Science of Food and Agriculture 85(14), 2453-2460.

Ohgren, K., Bura, R., Saddler, J., and Zacchi, G. (2007). "Effect of hemicellulose and lignin removal on enzymatic hydrolysis of steam pretreated corn stover," Bioresource Technology 98(13), 2503-2510.

Ooshima, H., Burns, D., and Converse, A. (1990). "Adsorption of cellulase from Trichoderma reesei on cellulose and lignacious residue in wood pretreated by dilute sulfuric acid with explosive decompression," Biotechnology and Bioengineering 36(5), 446-452.

Pan, X., Xie, D., Gilkes, N., Gregg, D., and Saddler, J. (2005). "Strategies to enhance the enzymatic hydrolysis of pretreated softwood with high residual lignin content," Applied Biochemistry and Biotechnology 124(1), 1069-1079.

Parajo, J. C., Alonso, J. L., and Santos, V. (1995). "Delignification and swelling of Eucalyptus wood ahead of enzymatic hydrolysis of the cellulosic fraction," Process Biochemistry 30(6), 537-545.

Ramos, L., Nazhad, M., and Saddler, J. (1993). "Effect of enzymatic hydrolysis on the morphology and fine structure of pretreated cellulosic residues," Enzyme and Microbial Technology 15(10), 821-831.

Ramos, L. P. (2003). "The chemistry involved in the steam treatment of lignocellulosic materials," Qumica Nova 26, 863-871.

Ride, J. P., and Drysdale, R. B. (1972). "A rapid method for the chemical estimation of filamentous fungi in plant tissue," Physiologial Plant Pathology 2(1), 7-15.

Saha, B. C., Iten, L. B., Cotta, M. A., and Wu, Y. V. (2005). "Dilute acid pretreatment, enzymatic saccharification, and fermentation of rice hulls to ethanol," Biotechnology Progress 21, 816-822.

Suarez-Garcia, F., Martinez-Alonso, A., and Tascon, J. (2002). "A comparative study of the thermal decomposition of apple pulp in the absence and presence of phosphoric acid," Polymer Degradation and Stability 75(2), 375-383.

Sun, Y., and Cheng, J. (2002). "Hydrolysis of lignocellulosic materials for ethanol production: A review," Bioresource Technology 83(1), 1-11.

Sun, Y., and Cheng, J. (2005). "Dilute acid pretreatment of rye straw and Bermuda grass for ethanol production," Bioresource Technology 96(14), 1599-1606. 
Taherzadeh, M., and Karimi, K. (2007). "Enzymatic-based hydrolysis processes for ethanol from lignocellulosic materials: A review," BioResources 2(4), 707-738.

Thambirajah, J. J., Zulkafli, M. D. and Hashim, M. A. (1995) "Microbiological and biochemical changes during the composting of oil palm empty fruit bunches: Effect of nitrogen supplementation on the substratre," Bioresource Technology 52, 133-134.

Umikalsom, M. S., Ariff, A. B., Zulkifli, H. S., Tong, C. C., Hassan, M. A., and Karim, M. I. A. (1997). "The treatment of oil palm empty fruit bunch fibre for subsequent use as substrate for cellulase production by Chaetomium globosum Kunze," Bioresource Technology 62(1-2), 1-9.

Wise, L., Murphy, M., and d'Addieco, A. (1946). "Chlorite holocellulose, its fractionation and bearing on summative wood analysis and on studies on the hemicelluloses," Paper Trade J. 122(2), 35-43.

Wood, T. M., and Bhat, K. M. (1988). "Methods for measuring cellulase activities," Methods in Enzymology 87-112.

Wyman, C., Dale, B., Elander, R., Holtzapple, M., Ladisch, M., and Lee, Y. (2005). "Comparative sugar recovery data from laboratory scale application of leading pretreatment technologies to corn stover," Bioresource Technology 96(18), 20262032.

Zeng, M., Mosier, N., Huang, C., Sherman, D., and Ladisch, M. (2007). "Microscopic examination of changes of plant cell structure in corn stover due to hot water pretreatment and enzymatic hydrolysis," Biotechnology and Bioengineering 97(2), 265-278.

Zhang, Y., Ding, S., Mielenz, J., Cui, J., Elander, R., Laser, M., Himmel, M., McMillan, J., and Lynd, L. (2007). "Fractionating recalcitrant lignocellulose at modest reaction conditions," Biotechnology and Bioengineering 97(2), 214-223.

Article submitted: September 27, 2010; Peer review completed: October 30, 2010; Revised version received: November 23, 2010; Article accepted: December 4, 2010; Published: December 7, 2010. 